Jason R Ali; Gary M Thompson; Xieyan Song; Yunliang Wang Journal of the Geological Society; Jan 2002; 159, Academic Research Library pg. 21

\title{
Emeishan Basalts (SW China) and the 'end-Guadalupian' crisis: magnetobiostratigraphic constraints
}

\author{
JASON R. ALI ${ }^{1}$, GARY M. THOMPSON ${ }^{2,1}$, XIEYAN SONG ${ }^{1.3}$ \& YUNLIANG WANG \\ ${ }^{1}$ Department of Earth Sciences, University of Hong Kong, Pokfulam Road, Hong Kong, P. R. China \\ (e-mail: jrali@hku.hk) \\ ${ }^{2}$ Beppu Geothermal Institute, Kyoto University, Noguchibaru, Beppu, Oita, 874-0903, Japan \\ ${ }^{3}$ Centre for Analyses and Research, Chengdu University of Technology, Chengdu, 610059, Sichuan, P.R. China
}

\begin{abstract}
A magnetostratigraphic investigation of the Permian Emeishan LIP (large igneous province) was carried out on a composite section in Ebian County, close to the type area in Sichuan, SW China. The main succession of twelve flows ( $175 \mathrm{~m}$ thick) carries a normal polarity whilst the one reliable site from the overlying $30 \mathrm{~m}$ thick volcanic waning sequence is marked by a reverse polarity. The data enable a corrclation to be proposed with an Emeishan Basalt sequence in western Guizhou, $c 400 \mathrm{~km}$ to the SE. From our knowledge of the geomagnetic field's reversal behaviour during the Permian, it suggests that the main lava pile along the eastern half of the Emeishan Basalt outcrop belt was erupted within a half to one million years. Using magnetobiostratigraphic data from the adjacent South China platform, the normal polarity magnetozone is correlated with the normal polarity chron associated with the upper part of the Maokou Limestones. Constrained by conodont data, the main Emei Basalts appear to be at least two biozones older (1-1.5 Ma) than the Mid-Late Permian boundary. It is possible, however, that the Emei Basalt waning zone sequence, which represents an explosive volcanic phase. might be coeval with the 'end-Guadalupian' biotic crisis. Thus arguments implicating Emei Basalt volcanism as the causal mechanism behind this major global event have to accommodate the new relative-age constraints.
\end{abstract}

Keywords: Sichuan; China; Permian, Guadalupian, magnetostratigraphy; extinction.

The Permian Emeishan Basalt Formation of SW China is recognized as one of Earth's Large Igneous Provinces (LIP) (e.g. Chung et al. 1998). Such terrains are geologically impressive with volumes of one-third to two million cubic kilometres erupted within one or two million years (White \& McKenzie 1995). Over the past three decades, much effort has been spent on understanding how LIPs are generated. Building upon the classic work of Morgan (1972), one group of models has focused on large mantle-plumes impacting on the base of the lithosphere (see for example the basic models of Richards et al. 1989: Campbell \& Griffiths 1990; White \& McKenzie 1989; Kent et al. 1992). The plume component has, however, been contested and several non-plume models have been proposed (e.g. Anderson et al. 1992; King \& Anderson 1995). In continental settings LIPs usually mark the sites of rifting and ocean basin formation (Courtillot et al. 1999). Additionally, many LIPs are temporally associated with major biotic crises, hence a causal link has been proposed although with varying degrees of enthusiasm (Courtillot 1999; Wignall 2001).

The Emeishan Basalts outcrop across an area of 0.25 0.3 million square kilometres in the provinces of Sichuan, Yunnan and Guizhou (Fig. 1). The unit has a volume of about 0.25 million $\mathrm{km}^{3}$ (Huang \& Opdyke 1998); the thicknesses vary widely across the terrain from one to two hundred metres in the eastern parts to somewhat localized highs in excess of five kilometers in the west (Liu \& Xu 1994, p. 139). The LIP has been studied palaeomagnetically by many scientists (e.g. McElhinny et al. 1981; Zhao \& Coe 1989; Van der Voo et al. 1993; Ma et al. 1993) almost exclusively to constrain the amalgamation of several crustal blocks (e.g. South and North China, Tarim and Indochina) to eastern Eurasia in the
Mesozoic. Thomas et al. (1998) also studied the unit for tectonics, although their primary aim was to obtain geomagnetic field intensity information following the $40 \mathrm{Ma}$ long Permo-Carboniferous (Kiaman) Reversed Superchron. From these and other works it is well established that the basalt pile is: (1) dominated by normal polarities: (2) was erupted at an equatorial location; (3) records a clockwise rotation of about $15-35^{\circ}$; and (4) includes a small number of reverse polarity directions that are not exactly antipodal with respect to the normally magnetized directions. This has led some workers to question whether the remanence of the unit is primary (Van der Voo et al. 1993).

The only focused magnetostratigraphic investigation (Huang \& Opdyke 1998) involved a flow-by-flow study through a $550 \mathrm{~m}$ thick sequence at Duge, c. $30 \mathrm{~km}$ south of Liupanshui in western Guizhou Province. However, the principal aim of the study remained tectonic; by assessing the contribution of normal/reverse polarity flows within the Emeishan dataset Huang \& Opdyke (1998, pp. 1-2) anticipated being able to address the antipodality issue and hence evaluate the directional data within the context of plate modeling. Our motive for carrying out magnetostratigraphic studies is somewhat different and directed towards understanding the Emei Basalts' relationship with the 'end-Guadalupian' extinction. According to Stanley \& Yang (1994), the event was one of the most severe Phanerozoic crises with more than $70 \%$ of the marine species dying out at this time (see also Wang \& Sugiyama 2000). A recent SHRIMP zircon dating study of Emei Basalt-related intrusive rocks has yielded ages of $258.7 \pm 1.5$ and $256.0 \pm 1.0 \mathrm{Ma}$ (Zhou et al. 2001). Zhou et al. (2001) used these data and stratigraphic information from the adjacent coeval South China platform sequences to provide the 


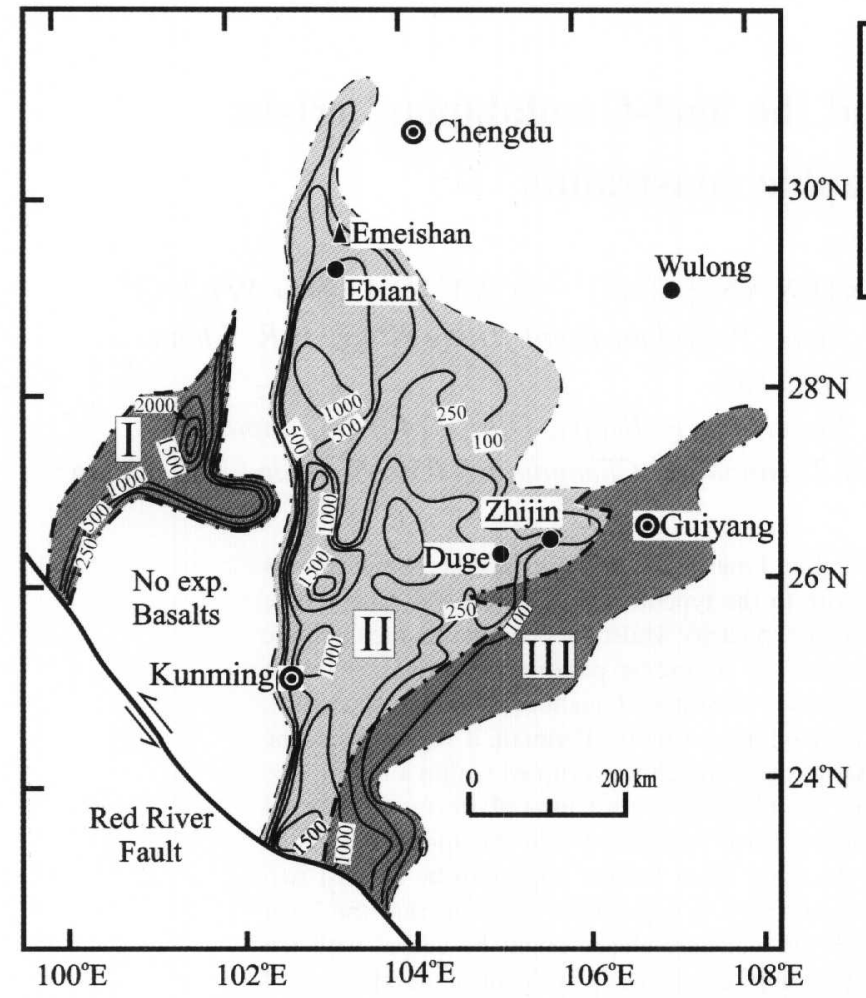

first clear evidence for the close temporal link between the Emei Basalts and the end-Guadalupian extinction.

\section{Geology}

Although the Emeishan Basalts and associated rocks have been extensively documented (e.g. Wang et al. 1987; Anon 1991), during fieldwork it became apparent that the published works and generalizations made for stratigraphy of the Emeishan Basalts and associated rocks in Ebian County (and Mt Emei area) are somewhat confusing. The sub-regional stratigraphy has recently been reviewed (Thompson et al. 2001), and the scheme is summarized in Figure 2. The sequence in the Ebian area is similar to that at Emei, the principal difference being the thickness of the main basalt pile (respectively, $175 \mathrm{~m}$ and $270 \mathrm{~m}$ ). The basalts conformably overlie a several hundred metre thick shelf limestone sequence of the Middle Permian Maokou Formation and comprise of one dozen flows ranging in thickness from 6 to $35 \mathrm{~m}$. The upper parts of Flows 1 to 11 are relatively fresh and no palaeosols were observed to have developed between flows, suggesting a relatively short time, perhaps, less than a few tens of thousand years between eruptions (a full discussion of this is provided in Thompson et al. 2001, where palaeonvironmental information deduced primarily from palynological data provides the key evidence). However, the upper third of Flow 12 is conspicuous for being intensively palaeoweathered. The main basalts are succeeded by a complex package of rocks including thin basalts, tuffaceous rocks, pyroclastic deposits and terrestrial sediments assigned to the newly proposed Xin Chung Member (Thompson et al. 2001). The unit is about $30 \mathrm{~m}$ thick and marks the waning of volcanism. It is overlain by the Lower Triassic Feixianguan Formation, comprising terrestrial sandstones and mudstones.
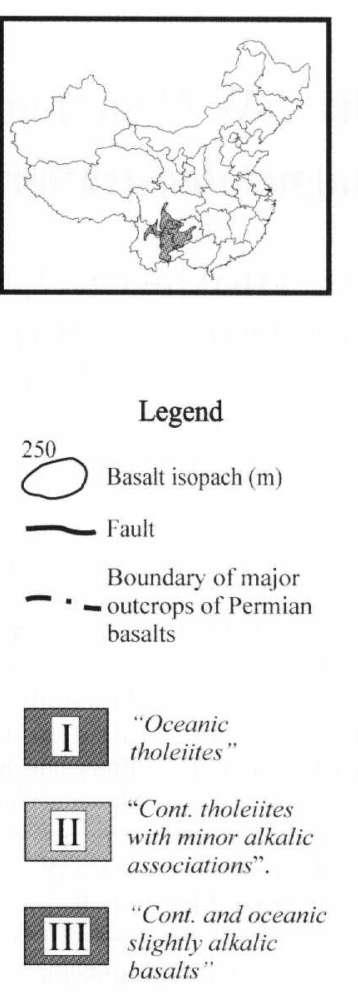

Fig. 1. Outcrop-subcrop map of the Emeishan Basalts (based on Liu \& Xu 1994 and Thompson et al. 2001). Note also the South China Platform section at Wulong that was studied by Heller et al. (1995).

\section{Methods}

Standard six- or seven-sample palacomagnetic sites were collected from the plagioclase phyric/aphyric lower-middle portions of each flow. Flow tops were avoided as they are almost always riddled with amygdales and show signs of alteration. Cores, $2.5 \mathrm{~cm}$ in diameter, were sampled using a gasoline-powered rock drill and oriented using a Brunton Compass mounted on a Pomeroy Orientation Table. To supplement the dataset, two-/three-sample 'mini-sites' were collected from the middle/upper parts of some flows in the section at Xin Chung village. The natural remanent magnetization (NRM) of each sample was measured using an AGICO JR5A magnetometer. Most of the specimens were magnetically cleaned using alternating field (af) demagnetization in a Molspin tumbler system. Thermal demagnetization (using a Magnetic Measurements instrument) was carried out on a minority of specimens, mainly on samples that did not respond to af treatment, but also on representative ones to determine unblocking temperatures and thereby provide information on the remanence carriers. Demagnetization data were examined using a Core Magnetics software package. Vector end point diagrams (Zijderveld 1967) were used to analyse the data from each sample and principal component analysis (Kirschvink 1981) was used to determine characteristic magnetization (ChRM) directions. An overwhelming number of samples exhibited a high-stability remanence with either no other component or an easily removed viscous remanence (e.g. Fig. 3a, b), suggesting a simple magnetization history. The thermal demagnetization studies indicate that for most sites the remanence is carried by magnetite. However, samples from a small number of sites exhibited unusual bchaviour and these are commented upon in the outcrop discussions below. The statistics of Fisher (1953) were used to calculate site mean directions (Table 1). The sub-regional magnetostratigraphy is summarized in Figure 4.

\section{Results: Ebian}

The uppermost $30 \mathrm{~m}$ of the Maokou Formation and the lower half of the Emeishan Basalts, locally labeled Flows 1-7, are exposed several kilometres along the road from Ebian to Emei, 


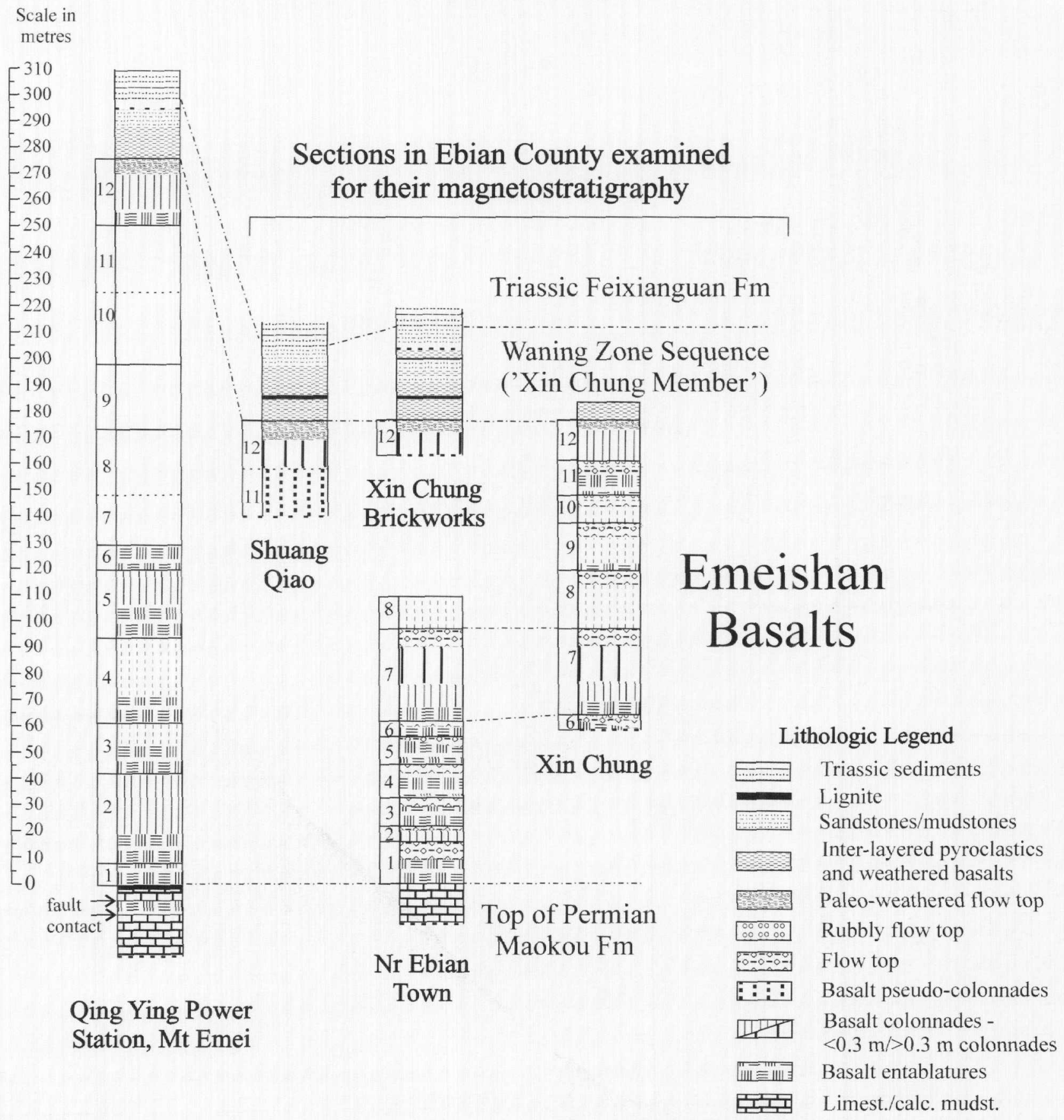

Fig. 2. Stratigraphic summary of the sections in Ebian County area examined for their magnetostratigraphy based on Thompson et al. (2001). For reference the section examined at Mt Emei is shown also. Where flows are too poorly exposed to determine their internal structure they are left blank. Dashed lines indicate that the contact between flows or units is obscured or questionable. Although twelve flows are recognized at Emei and Ebian, a flow-by-flow correlation is not inferred.

at $29^{\circ} 16.139^{\prime} \mathrm{N} / 103^{\circ} 16.392^{\prime} \mathrm{E}$. The rocks have a westerly dip and are inclined at $48^{\circ}$. The magnetization of this sequence is simple: each site carries a normal polarity magnetization (Fig. 4). However, there are two points worthy of comment. Firstly, in Sites EB4 and EB7 there are substantial differences in NRM intensities for the site subsets. This is most likely due to the samples being collected from different along-strike parts of the same flow where rocks with different magnetic grain concentrations were sampled. Secondly, there is a clear directional difference $\left(28^{\circ}\right)$ between the two EB4 site subsets.
Because of this, the site is not included in the outcrop-mean direction calculation, which in tilt corrected coordinates is Dec $=14.5^{\circ}$, Inc $=10.3^{\circ}$ where $N=6, a 95=5.9^{\circ}$ and $k=131.7$ (Table 1).

\section{Results: Xin Chung}

The section adjacent to and just below the village of Xin Chung, at $29^{\circ} 17.933^{\prime} \mathrm{N} / 103^{\circ} 16.466^{\prime} \mathrm{E}$, exposes the upper half of 


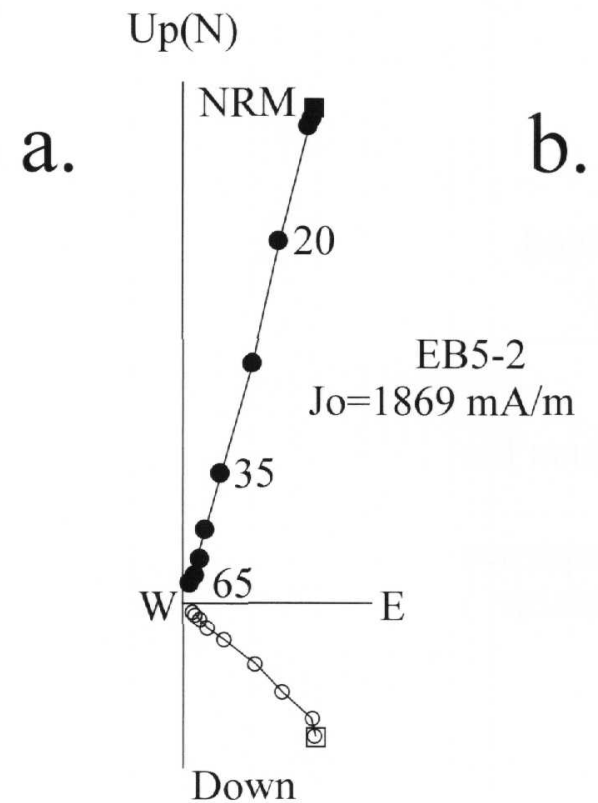

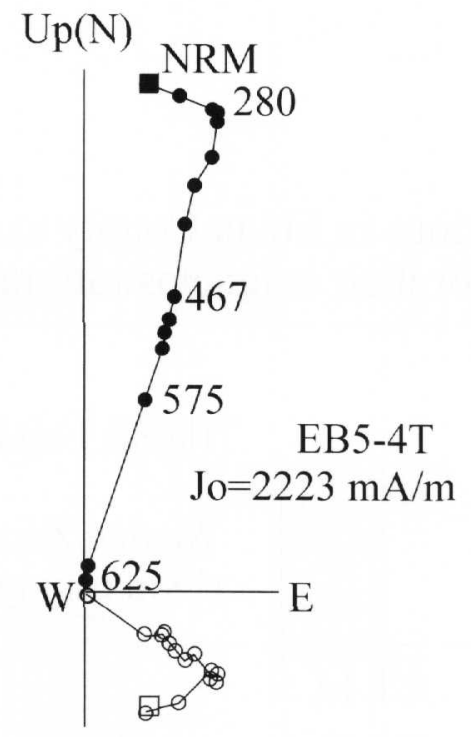

Down

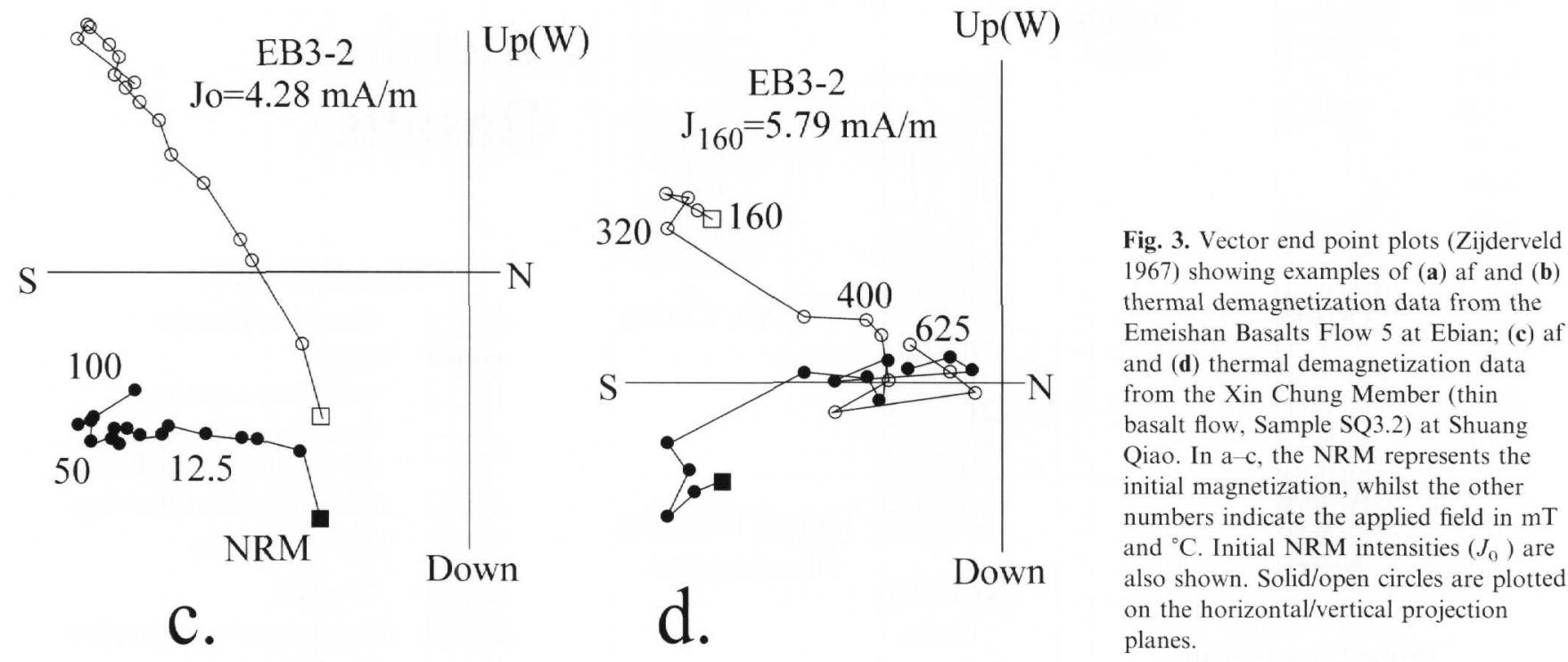

the main Emeishan Basalt sequence (locally labeled Flows 6-12), the weathered upper part of Flow 12 and the lower part of the waning zone interval (Xin Chung Member). The rocks dip toward $285^{\circ}$ at $23^{\circ}$. As with the Ebian section the magnetization is simple; all sites from the main basalt sequence carry a normal polarity remanence (Fig. 4 and Table 1), with the following exceptions. One of the six samples from Site XC4 carries a reverse polarity, with a ChRM exactly antipodal to the main directional group from this site. It is possible that this sample was collected incorrectly, but it would have to have been inverted, mis-marked and to then have 'survived' the tilt-correction, hence it is considered unlikely. Secondly, data from Flow 6 (Site XC1) have not been used to calculate a site mean direction; the ChRMs for each of the samples from this site are all normal polarity magnetized but the directions show a smeared distribution. Hence inclusion of the site mean in the outcrop mean calculation would effectively degrade the dataset. Thirdly, most of the flows that were sampled at two levels showed effectively similar directions (e.g. XC8/9 in Flow 10). However, some paired flow sites showed significant differences (e.g. XC11/12 in Flow 12), which is contrary to basic palaeomagnetism theory. A feature encountered in several of the Emeishan Basalt flows are low angle, relative to flow tops/ bottoms, 6-10 cm wide ductile shear zones, which are interpreted to mark slump movements of the lava flow as the body crystallized (the middle-upper parts of the flow being more likely to be affected than the lower parts). Movement along such surfaces, post remanence acquisition, might explain the directional differences between different parts of the same flow. An alternative explanation of prolonged cooling/remanence acquisition would require magnetic blocking to take place over periods of centuries if recent secular variation rates are used as a guide (e.g. Malin \& Bullard 1981) and thus can be excluded. Because of these various points, the tilt-corrected outcrop mean direction 
MAGNETOSTRATIGRAPHYY, EMEISHÀ̀ BASALTS, SW CHINA

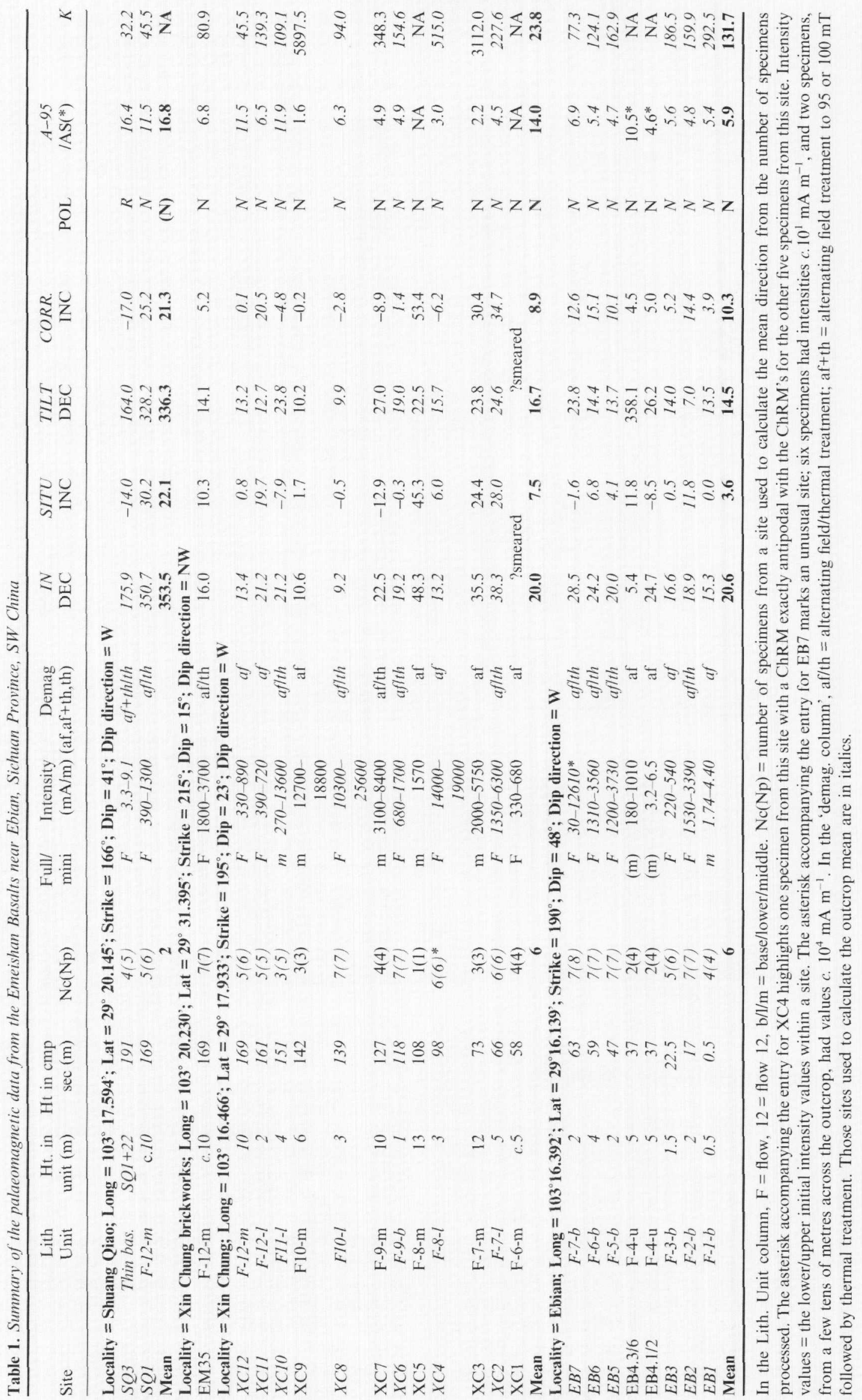




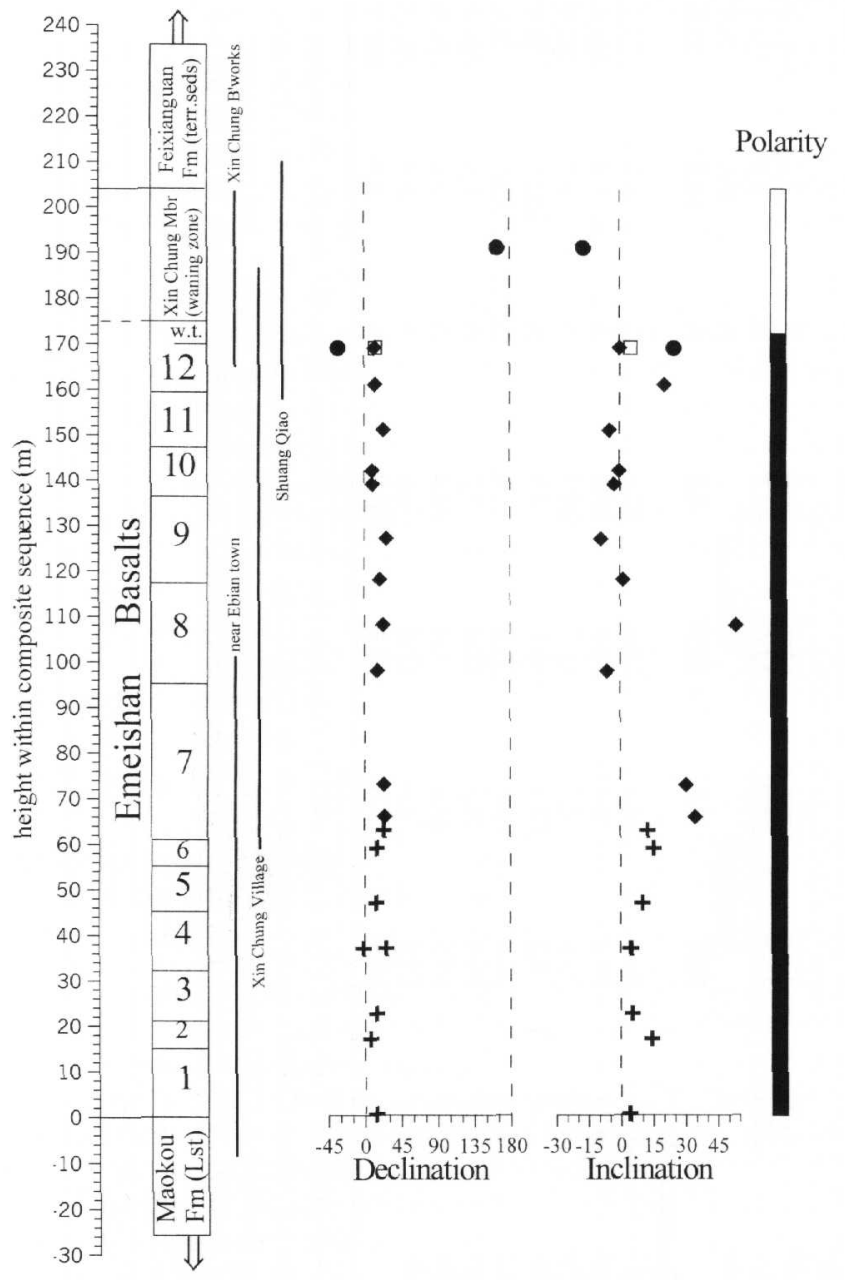

Fig. 4. Magnetostratigraphic summary of the Emeishan Basalts based on the study of sections near Ebian (crosses), Xin Chung village (diamonds), Xin Chung Brickworks (open square) and Shuang Qiao (circles) in Sichuan Province. The bars to the right of the stratigraphic column indicate the range of each section. Polarity interpretation: black indicates normal; white indicates reverse.

(Dec $=716.7^{\circ}, \quad$ Inc $=8.9^{\circ}$ where $N=6, \quad a 95=14.0^{\circ}$ and $k=23.8$ ) has been calculated using only the 'full' sites from the lower part of each flow (Table 1).

\section{Results: Xin Chung Brickworks and Shuang Qiao}

Stratigraphically, the nearby sections at Xin Chung Brickworks $\left(29^{\circ} 31.395^{\prime} \mathrm{N} / 103^{\circ} 20.230^{\prime} \mathrm{E}\right)$ and Shuang Qiao $\left(29^{\circ} 20.145^{\prime} \mathrm{N} / 103^{\circ} 17.594^{\prime} \mathrm{E}\right)$ are very similar and, because they were sampled at just one and three sites respectively, are discussed together in this section. The road-cuttings adjacent to the Xin Chung Brickworks expose the middle and upper part of Emeishan Basalt Flow 12 and the entire Xin Chung Member volcanic waning interval. Although the succession is fresh enough to establish the stratigraphy (Thompson et al. 2001), there are few horizons suitable for palaeomagnetism sampling and only the unweathered mid Flow 12 rocks were collected (which dip $15^{\circ}$ towards $305^{\circ}$ ). The single site, EM35, carries a normal polarity magnetization with a tilt corrected mean direction of Dec $=14.1^{\circ}$, Inc $=5.2^{\circ}($ Fig. 4, Table 1$)$.
The river section just south of Shuang Qiao town exposes a much fresher sequence of rocks than at the Xin Chung Brickworks. Three sites were sampled, one on the east side of the river (SQ1) from Flow 12, and two from the waning zone sequence on the west bank, in an ignimbrite (SQ2) and a thin basalt (SQ3). The rocks dip $41^{\circ}$ towards $256^{\circ}$. The ignimbrite did not yield useful directional data. All of the samples from Site SQ1 yielded simple demagnetization and carry normal polarity magnetizations. Samples from Site SQ3 showed more complex behaviour; af demagnetization (to $100 \mathrm{mT}$ ) had little impact and often the magnetic intensity increased with the applied field (Fig. 3c). Thermal cleaning was more effective, but as can be seen from Figure 3d, the samples yielded somewhat noisy demagnetization behaviour. Also at the high temperature steps $\left(600{ }^{\circ} \mathrm{C}\right.$ and beyond) some of the samples disintegrated or showed large intensity gains/directional shifts suggesting chemical alteration. Nevertheless, it was possible to determine ChRM directions for the four samples from this site which all carry reverse polarities. Both SQ1 and SQ3 are counter-clockwise deflected (Fig. 4, Table 1). When the SQ3 site mean direction is inverted, the two sites yield a tilt corrected mean of Dec $=336.3^{\circ}$ and Inc $=21.3^{\circ}$, where the angular separation is $16.8^{\circ}$ (Table 1 ).

\section{Primary versus secondary magnetization}

Together, the four studied outcrops form a composite section that spans the Emeishan Basalts and the waning zone sequence. The main twelve-flow basalt pile carries a normal polarity magnetization, whilst the waning zone sequence (at Shuang Qiao) records a reverse polarity. Before exploring the significance of the new data, the previously mentioned 'antipodality issue' needs to be scrutinized as it raises serious implications for magnetostratigraphic studies of the LIP (and regional tectonic modeling). It has been suggested (e.g. Van der Voo et al. 1993) that the Emeishan Basalts normal polarity sites (clustered with NNE declinations) carry secondary remagnetizations whereas the reverse polarity sites (with SW declinations) preserve a primary signal. This is based on the observation that, when plotted as apparent poles, the normal polarity directions plot closer to the Triassic pole of the South China Block than do the reverse directions (three studies reported in 1986 and the 1993 paper). However, the dataset underpinning this argument (Van der Voo et al. 1993, Table 1, reverse polarity site entry numbers $5,6.3,7.2$ and 8.2 ) is somewhat limited. The maximum number of samples for an individual study, $N$, is 12; cf. Van der Voo's (1990, 1993) widely used quality criteria list where it is suggested that for an individual direction $N$ should greater than 24 .

The information and discussions provided by Ma et al. (1993), Huang \& Opdyke (1998) and Thomas et al. (1998) throw light on the problem, either explicitly arguing or implicitly suggesting that the Emeishan Basalt normal polarity remanence is primary in each of the areas investigated. The data obtained in this study also suggest the Ebian county sections record primary magnetizations. Firstly, some of the paired flow sites from Xin Chung have mean directions that are quite separate; such dispersion would be difficult to induce during a remagnetization event. Secondly, the Shuang Qiao section records almost antipodal normal and reverse polarity directions within the same section. Thirdly, there is no hint of a systematic reversed component in any of the normal polarity sites, thus if the rocks were remagnetized the process was so efficient no trace of the original remanence was preserved. 


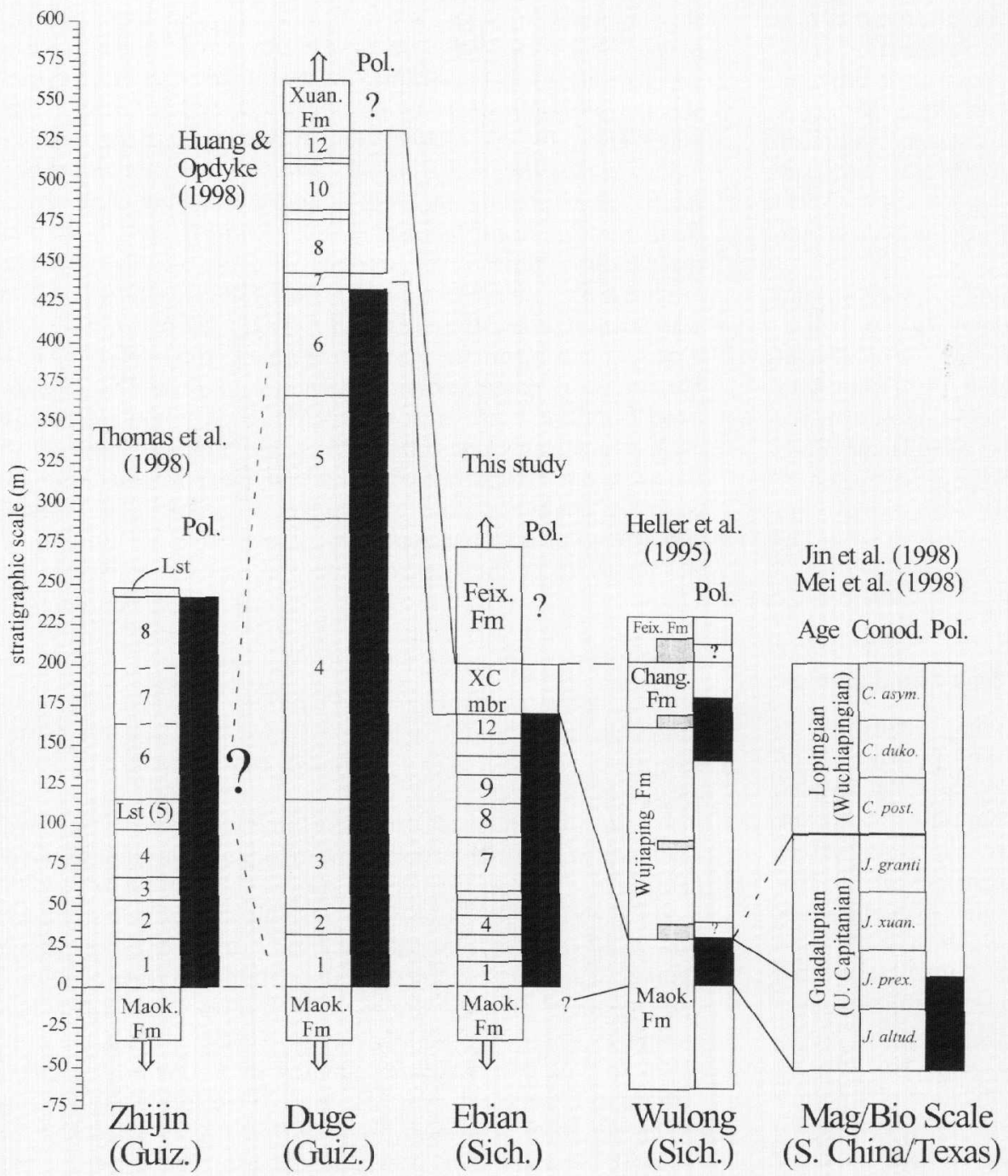

Fig. 5. Correlation of the Emeishan basalts from the Ebian County composite section (this study) with those reported from Zhijin (Thomas et al. 1998); Duge (Huang \& Opdyke 1998); South China Platform sequences at Wulong (Heller et al. 1995); and the Mid-Late Permian magnetobiostratigraphic scale (Jin et al. 1998; Mei et al. 1998). Magnetostratigraphic/lithostratigraphic ties are shown with solid/dashed lines. At Wulong, the lithologies are primarily limestones; shale beds correspond to the shaded half-column blocks. Polarity interpretation: black indicates normal; white indicates reverse: ? indicates indeterminate.

\section{Summary and regional correlations}

The magnetization in the Emeishan Basalts in Ebian County is considered to be primary. The basalt pile is normal polarity magnetized and this magnetozone is overlain by a reverse polarity site (SQ3) from the Xin Chung Member. Because the between-flow intervals are considered to be geologically short (see Thompson et al. 2001), the flows must have erupted within a single normal polarity field state. As a consequence of this argument, based on Opdyke's (1995, fig. 1) magnetostratigraphic synthesis, the basalts were probably erupted in less than $1 \mathrm{Ma}$. Such rapid voluminous outpouring of lava is one of the distinguishing features of continental flood-basalt (CFB) provinces (e.g. the Siberia CFB, Lind et al. 1994; Ethiopia CFB, Rochette et al. 1998).

As discussed above, many palaeomagnetic studies have been carried out on the Emeishan Basalts. However, only two are in a form appropriate for use in regional magnetostratigraphic discussions, both being in sequences from western Guizhou Province around $400 \mathrm{~km}$ to the southeast of Ebian. The composite section reported at Duge $\left(26.4^{\circ} \mathrm{N} / 104.7^{\circ} \mathrm{E}\right.$; Huang \& Opdyke 1998) is $550 \mathrm{~m}$ thick and is made up of twelve units. Units 1-6 (0-449 $\mathrm{m})$ carry normal polarity magnetizations; there are no data from Flow 7, Units 8-12 (459-551 m) carry reverse polarities (Fig. 5). An interesting aspect of the Duge section is that Units $1-6$ are proper flows, whereas units 7-12 comprise relatively thin flows (8 and 10) intercalated with tuffaceous rocks and/or agglomerate or pyroclastic breccia. Based on lithology, Thompson et al. (2001) correlated the Emei-Ebian sections with the one at Duge tying respectively the waning zone rocks (Xin Chung Member) with units 7-12. The magnetostratigraphic results obtained from the Ebian area appear to strengthen this link.

In contrast, the section studied by Thomas et al. (1998) at Zhijin $\left(26.5^{\circ} \mathrm{N} / 105.7^{\circ} \mathrm{E}\right)$ complicates the seemingly straightforward regional correlation. It is quite different to the sections at nearby Duge and the more distant outcrops at Ebian (and Emei) in Sichuan. The $260 \mathrm{~m}$ thick volcanic sequence formed in two distinctive phases separated by a significant period when $20 \mathrm{~m}$ of limestone was deposited. As Thomas et al. (1998) pointed out, the presence of a substantial shelf limestone package within the middle of the succession required local subsidence of the sub-aerially erupted lava pile to several tens of metres or more below sea-level followed by uplift and a second phase of volcanic activity. The first volcanic episode comprises two proper flows that are each overlain by volcanic breccias, whilst the second phase is in the form of three flows that span $130 \mathrm{~m}$ of section. A notable feature of the 
palaeomagnetic data from the igneous rocks (all sites record a normal polarity) is that the seven tilt-corrected site mean directions (Thomas et al. 1998, table 2) appear quite different from those reported elsewhere in the province (e.g. Huang \& Opdyke 1998), with many being appreciably steeper and more clockwise deflected. Interestingly, the limestone unit site $(\mathrm{GZ05})$ carries a direction $\left(\mathrm{Dec}=22.9^{\circ}\right.$ and $\left.\mathrm{Inc}=-22.9^{\circ}\right)$ more similar to that commonly encountered in studies of the Emeishan Basalts.

Clearly the quite different stratigraphies (litho- and magneto-) in the two Guizhou sections indicate that provincewide correlations should be developed with caution. Unfortunately, there are no other data with which the Ebian area magnetostratigraphy can be compared in detail. However, the basic stratigraphic results discussed above, that is the Emei Basalts carry a predominantly normal polarity, is supported by numerous tectonically oriented palaeomagnetic works that have been carried out on the LIP (see the synthesis in table 2 of Huang \& Opdyke 1998).

\section{Emeishan Basalts: age and link to the 'end-Guadalupian'}

Studies of numerous LIPs indicate that they are emplaced rapidly. The newly obtained radiometric data by Zhou et al. (2001) provide tight constraints on the age of the Emei Basalts. However, there are not enough ages to accurately bracket the interval of volcanism (also the dates are from intrusive rather than extrusive rocks, and the exact age relations of the two suites are not known). Unfortunately, the available biostratigraphic data from the unit and directly associated rocks provide only a limited relative-age/duration control; the Emei continental-rift LIP is succeeded by Upper Permian-Lower Triassic terrestrial sediments whose chronostratigraphic potential is somewhat restricted. Nevertheless, in recent years various pieces of information have been published that permit a relative age/duration discussion for the unit to be developed.

The study by Heller et al. (1995) provides some of the most useful data. They carried out a thorough magnetostratigraphic investigation of three Middle Permian-Lower Triassic sequences on the western part of the South China platform. Drawing attention to the limitations of their dataset, they presented a conservative interpretation and discussion. The results from the section at Wulong $\left(29^{\circ} \mathrm{N}, 107^{\circ} \mathrm{E}\right.$; less than $500 \mathrm{~km}$ from the Ebian-Emei and Duge-Zhijin areas, Figure 1) can be related directly to the Emei Basalt sequences discussed/ reviewed herein. At Wulong, the lower two-thirds of the Maokou Limestone (Fig. 5) records a reverse polarity, whilst the upper $30 \mathrm{~m}$ or so of the unit is marked by normal polarity (Heller et al. 1995, fig. 7b). The $10 \mathrm{~m}$ thick shale unit marking the lower part of the overlying Wujiaping Formation did not yield any useful data; the lower $105 \mathrm{~m}$ of the main Wujiaping limestones above carry a dominantly reverse polarity.

In terms of South China Mid-Late Permian regional correlations, the major synthesis by Sheng \& Jin (1994) provides a stratigraphic scheme that permits the Emei Basalts (from Ebian and Duge) to be compared with the platform sequences at Wulong (Fig. 5). Based on the available data it would seem appropriate to correlate the 'Emei Normal' with the 'Maokou Normal'. Such a proposal remains consistent with the observation of Thompson et al. (2001) where the Emei Basalts are noted to rest conformably on top of the Maokou Limestones. More importantly, it enables the Emei Basalts for the first time to be related to the Middle and Late Permian magnetobiostratigraphic scale (e.g. Jin et al. 1998). Such a correlation, when constrained by the detailed conodant biostratigraphic scheme developed from sections in South China and Texas (Jin et al. 1998, fig. 3; Mei et al. 1998, fig. 1), indicates that the main Emei Basalts (i.e. the normal polarity levels) must predate the Mid-Late Permian boundary by a small but significant amount (1.0-1.5 Ma; Fig. 5). The end of the Maokou Normal corresponds with the mid Jinogondella prexuanhanenis biozone and two other full zones (Jinogondello xuanhanensis and Jinogondella granti) are recognized in the late Guadalupian before the start of the Late Permian (Lopingian). However, the reverse polarity waning zone rocks that cap the Emei Basalts can probably be regarded as representing a more explosive volcanic phase than the underlying lava flows. Thus the idea that Emei LIP volcanism and the 'end-Guadalupian' crisis are 'cause and effect' related (e.g. Coutillot 1999; Wignall 2001) remains a viable hypothesis. However, it would require the 'cause' to be the later/terminal phase of volcanism.

\section{Conclusion}

A magnetostratigraphic investigation of the Permian Emeishan flood-basalts has been carried out on a composite sequence, comprising two extended sections and two short sequences, around $50 \mathrm{~km}$ south of the type area in Sichuan Province, SW China. The bulk of the lava pile (twelve flows spanning $175 \mathrm{~m}$ ) was erupted during a single normal polarity field state. The rocks generated during the Emeishan Basalts terminal phase were magnetized during a reverse polarity field. The data support observations from other LIPs in which magma generation occurs typically within one to two million years (probably $0.5-1.0 \mathrm{Ma}$ in the case of the Emei LIP). The section at Ebian-Xin Chung can be correlated with the only other section that has been studied in a similarly detailed fashion in Guizhou Province, some $370 \mathrm{~km}$ to the SE (Huang \& Opdyke 1998). However, we note that a second sequence in Guizhou (Thomas et al. 1998) cannot be correlated; neither the stratigraphic succession nor the magnetic polarity data can be matched.

Using magnetobiostratigraphic data from the nearby South China Platform, the 'Emei Normal' is correlated with a normal polarity magnetozone associated with the upper part of the Maokou Limestones. Using the Permian magnetobiostratigraphic scale, it indicates that the end of this normal polarity chron predates the end of the Guadalupian by at least two conodont biozones. Hence the bulk of the Emei LIP volcanism appears to have occurred $1.0-1.5 \mathrm{Ma}$. before this global extinction event. However, it is possible that the LIP's volcanic waning phase is linked to the event; the generated rocks are of a more appropriate relative age and are characterized by explosive lithologies. Thus their eruption could have severely impacted the end-Guadalupian Earth-Ocean-Climate system, which in turn could have led to the biotic crisis.

Future magnetobiostratigraphic studies of other Emei Basalt sections and South China Platform sequences should elucidate the basic stratigraphic relationships deduced by this study. The end-Guadalupian marked an important time in Earth's history, and establishing the exact link, if one exists, between it and the Emei Basalt LIP is critical for geological investigations of rapid planetary change.

Financial support by the HKU CRCG to J.R.A. and the HKU Stephen S.F. Hui Fund to G.M.T. funded this research. Yugan Jin 
(Nanjing) is thanked for his discussions on Middle and Late Permian stratigraphic issues. Friedrich Heller (Zurich), Tetsuo Sugiyama (Fukuoka) and Meifu Zhou (Hong Kong) kindly supplied pre/reprints. Review comments by Mark Allen, Sally Gibson, Pierre Rochette, Nick Rogers, Rob Van der Voo and an anonymous referee greatly improved the manuscript.

\section{References}

ANOX 1991. [Regional Geologl of Sichuan Provinc]. Geological Memoir Series. 23. Geological Press. Beijing [in Chinese]

Anderson, D.L.. Zhang, Y.S. \& Tanimoto. T. 1992. Plume heads, continental lithosphere, flood basalts and tomography. In: STOREy, B.C., Alabascer. T. \& PANkhurst, R.J. (eds) Magmatism and the causes of continental breuk-up. Geological Society, London, Special Publications, 68, 99-124.

CAMPBELL, I.H. \& GRIFFITHS. R.W. 1990. Implications of mantle plume structure for the evolution of flood basalts. Earth \& Planeiary Scionce Letters, 99. $79-93$.

Chung, S.L.. JaHN-B. M., W. G.Y., Lo, C.H. \& Cong. B. 1998. The Emeishan flood basalt in SW China; a mantle plume initiation model and its connection with continental breakup and mass extinction at the PermianTriassic boundary. In: Flower. M.F.J., Chung. S.L.. Lo. C.H. \& LeE. T.L. (eds) Mantle dynamics and plate interactions in East Asia. AGU Geodynamics Series, 27, 47 58 .

Cotrillot, V. 1999. Evolutionary Catastrophes. Cambridge University Press. Cambridge.

Courtillot, V.. Jaupart, C., Manighetti, I., Tapponnifr. P. \& Besse, J. 1999. On causal links between flood basalts and continental breakup. Eurth \& Planetary Science Letters, 166, 177--195.

Fisher. R.A. 1953. Dispersion on a sphere. Proceedings Roval Society London, A217, 295-305.

Heller, F., Chen, H., Dobson, J. \& HaAG, M. 1995. Permian-Triassic magnetostratigraphy - new results from South China. Physics of the Earth and Planetary Interiors, 89. 281-295.

HuANG, K. \& OPDYKE, N.D. 1998. Magnetostratigraphic investigations of an Emeishan basalt section in western Guizhou Province. China. Earth \& Planetary Science Letters, 163, 1-14.

Jin, Y MeI, S Wang, W Wavg, X. Shev, S Shanici, Q \& Chev, Z 1998. On the Lopingian Serics of the Permian System. Palaeoworld, 9, 1-19.

Kent, R.W., Storfy, M. \& Saunders, A.D. 1992. Large igneous provinces: sites of plume impact or plume incubation? Geology, 20, 891-894.

King. S.D. \& ANDFrson. D.L. 1995. An alternative mechanism of flood basalt formation. Earth \& Planetary Science Letters, 136, 269-279.

Kirschyink, J.L. 1980. The least squares line and plane analysis of paleomagnetic data. Geophysical Journal Roval Astronomical Societv. 62 $699-718$.

Lind, E.N., Kropotov, S.V., Czammanske, G.K., Gromme, S.S. \& Fedorfnko. V.A. 1994. Paleomagnetism of the Siberian flood basalts of the Noril'sk area: a constraint on eruption duration. International Geologl Review. 36, $1139-1150$

LIU. B. \& XL, X. 1994. Atlas of the lithofacies and paleogeograply of South China ( Sinian-Triassic). Science Press, Beijing.

MA. X.. MCElitinny, M.W., Emri.fon, B.J.J. \& Zhang. Z. 1993. PermoTriassic paleomagnetism in the Emei Mountain region, southwest China. Geophysical Journal International, 114. 293 303.

Mairi, S.R.C. \& Bull.ard, E. 1981 . The direction of the Earth's magnetic field at London, 1570-1975. Philosophical Transactions of the Royal Socicty. London. A299, 357-423.

McElhinny, M.W., Embleton, B.J.J., MA, X. \& Zhavg, Z. 1981. Fragmentation of Asia in the Permian. Nature, 239, 163-169.
MEI, S. JIY, Y. \& WArdolow, B.R. 1998. Conodont succession of the Guadalupian-Lopingian boundary strata in Laibin of Guangxi. China and west Texas. USA. Palacoworld, 9, 53-76.

Morgan, W.J. 1972. Plate motions and deep mantle convection. Geological Soctety of America Memoirs. 132. 722.

OPDYKT, N.D. 1995. Magnelostratigraphy of Permo-Carboniferous time. $\mathrm{m}$ : Berggrfen. W.A.. Kent, D.V., Aubry, M.P. \& Hardenbol. J. (eds) Geochronology, time scales and stratigraphic correlation: framework for an historical geology. SEPM Special Publications, 54, 271-274.

Richards, M.A., DUNCan. R.A. \& Courtillot, V.E. 1989. Flood basalts and hotspot tracks: plume heads and tails. Science, 246, $103-107$.

Rochette. P., Tamrat, E.. Frraud, G.. Pik, R., Courtillot, V., Ketefo, E. Coulon, C.. Hofmann, C. Vandammme, D. \& Yirgu, G. 1998. Magnetostratigraphy and timing of the Oligocene Ethiopian Traps. Earth \& Planetary Sitince Letters. 164. 497-510.

Sheng, J. \& Jin. Y. 1994. Correlation of Permian deposits in China. Palaeorrorld. 4, 14113 .

STANIFY, S.M. \& YANG, X. 1994. A double mass extinction at the end of the Palcozoic Era. Science, 291, 1340-1344.

Thomas, D.N.. Rolpi, T.C., Sitaw, J., Gonzalez de Sherwood, S. \& Zhuavg. Z. 1998. Palaeointensity studies of a late Permian lava succession from Guizhou Province. South China: implications for post-Kiaman dipole field behaviour. Geophysical Joumal International. 134. 856-866.

ThOMPson, G.M.. AI.I, J.R., SONG, X. \& JOLLEY, D.W. 2001. Emeishan Basalts southwest China: reappraisal of the formation's type area stratigraphy and a discussion of its significance as a LIP. Jownal Geological Soctery. Londor. . 158, 593-599.

VAN DER VOO, R. 1990. The reliability of paleomagnetic data. Tectonophysics. 184. $1-9$.

VAN DER VOO. R. 1993. Palcomagnetism of the Allantic, Tethys and Iapetus Oceans. R. Paleomagnetism of the Atlantic. Tethys and Iapetus Occans. Cambridge University Press, Cambridge.

VAN der VoO, R. WL, F.. WhNG. Z., Suk, D.. Peacor, D.R. \& Liang. Q. 1993. Paleomagnetism and electron microscopy of the Emeishan basalts. Yunnan, China. Tectonophysics, 221, 367-379.

Wang, X.D. \& Sugryama, T. 2000. Diversity and extinction patterns of Permian coral faunas of China. Lothaia, 33, 285-294

Wavg, Y.. Li, J., Zhou, R.. Wang. W., Tovg, C. \& Xiong, S. 1987. /Principle on trace element geochemistry of igncous rocks and its applications and demonstration of the petrogenesis of the Emeishan basalts]. [Principle on trace element geochemistry of igneous rocks and its applications and demonstration of the petrogenesis of the Emeishan basalts.] Chengdu Science and Technology Publishing House, Chengdu. China [in Chinese].

WIGNALL, P.B. 2001. Large igneous provinces and mass extinctions. Earth-Science Reviens, 53. 133

White. R. \& MCKFNZIE, D. 1989. Magmatism at rift zones: the generation of volcanic continental margins and flood basalts. Jounal Geophysical Research, 94, 7685.7729.

White, R. \& MCKFvirif, D. 1995. Mantle plumes and flood basalts. Joumal Geophysical Research, 100, 17543-17585.

ZhAO. X. \& COF, R.S. 1989. Tectonics implications of Permo-Triassic results from North and South China. In: Hillhouse, J.W. (ed.) Deep Sracture and past kinematics of acreted terranes. AGU Geophysical Monographs, 5. 267-283.

Zhao, X.. Cof, R.S., Gilder. S.A. \& Frost, G.M. 1996. Paleomagnetic constraints on the paleogeography of China: implications for Gondwanaland. Australion Joumal Earth Sichess, 43, 643-672.

Zhou, M.F., Malpas. J., Song, X.Y., Robinson, P.T., Kennfid. A.K., Sli, M., Thompson. G. Yan. D. \& ZHavg, C.J. 2001. SHRIMP zircon geochronology of the Emeishan large igenous province (SW China): implications for double mass extinctions in the Late Permian. Eleventh Goldschmid Conference Virginia. Abstract No. 3519 